\title{
IMPROVEMENT IN THERMAL EFFICIENCY OF A CI ENGINE USING A WASTE HEAT RECOVERY TECHNIQUE
}

\begin{tabular}{|l|l|l|l|l|}
\hline Aashish Sharma & Ajay Chauhan & Himanshu Nautiyal & Varun & Pushpendra Kumar \\
Lovely Professional & Lovely Professional & THDC Institute of & National Institute of & Sharma \\
University, Phagwara, & University, Phagwara, & Hydropower & Technology, Hamirpur, & THDC Institute of \\
Punjab, India & Punjab, India & Engineering \& & (HP) India & Hydropower \\
aashish.16420@lpu.co.in & & Technology, Tehri, & & Engineering \& \\
& & Uttarakhand, India & & Technology, Tehri, \\
& h2nautiyal@gmail.com & & Uttarakhand, India \\
\hline
\end{tabular}

\begin{abstract}
A big portion of the heat supplied to an internal combustion (IC) engine is not converted into work and wasted through the exhaust gases in surroundings. If this heat is recovered or used by some means then improvement can be obtained in engine's overall efficiency. In the present work, an experimental work is carried out to study the effect of waste heat recovery of exhaust gas in a Compression Ignition (CI) engine. The results show that considerable reduction in engine fuel consumption can be obtained with the help of exhaust heat recovery through a heat exchanger. A significant amount of heat of exhaust gases can be recovered by vaporization of fuel using a heat exchanger.
\end{abstract}

Keywords—engine; efficiency; ignition; heat; recovery

\section{INTRODUCTION}

Energy has become an indicator of economic growth and social development of a country. Generally human consume the energy from fossil fuels and use this energy in various sectors of domestic and industrial activities as well as for their comfort. Almost all developing and developed countries in the world are dependent on fossil fuels to obtain energy but their contribution in problem of climate change has become a matter of great concern. Today the entire world is focusing on the proper and best use of fossil fuels so that the environmental problems associated with them can be reduced considerably. This has become a great interest for scientists and engineers to find out the suitable alternatives for using efficient use of fossil fuels and recovering heat so that wasted heat can be reduced. IC engines have become an integral part of all human and commercial activities in daily life and widely used in power generation, transportation and agricultural sectors. But today the need of demand reduction and low harmful emissions through the efficient engines is being increased. Advance technology has the major interest in recent years particularly in highly efficient IC engine. The IC engines have several applications and are commonly used in cars, aircrafts and boats etc [1]. But the problem of fuel crises due to their fast depletion nature, environmental impediments associated with them are putting a question mark in the using of IC engines in future. Therefore, it is important to think about the improvement of efficiency of IC engines.

IC engines transform about $25 \%$ to $35 \%$ chemical energy into mechanical work. About $70 \%$ of total energy is wasted through exhaust gas, coolant and radiation [2]. Exhaust gas temperature is high due to combustion process inside the cylinder, which cause cylinder wall temperature get high and proper cooling is required to minimize the cylinder wall temperature. Several industrial activities and processes in various sectors requires considerable amount of heat energy which generally not utilized efficiently. The wasted heat energy from the industries is transferred into the surroundings in the form of unburned fuels, sensible heat discharge from drain water and through sensible and latent heat through exhaust gases discharge. If this wasted energy is recovered by some means, better results in the performance of engine can be obtained. So, there is a big scope to recover wasted heat energy from IC engine and use it in some other applications. The wasted heat energy can be recovered efficiently through the combustion equipment to utilize wasted fuel and through heat recovery equipment to reuse sensible and latent heat through exhaust gases. Several efforts have been expended to reuse the wasted heat during past decades. This work describes the utilization of waste heat which is coming through exhaust gas and the engine performance.

\section{LITERATURE REVIEW}

Waste energy from engine is normally a byproduct which is in form of heat. Energy is lost from the IC engine to the environment in the form of exhaust gas, cooling water, lubrication oil and radiation. Generally waste heat recovery is a technique, which enhance the performance of engine and can reduce the brake specific fuel consumption (bsfc) and consequently thermal efficiency is improved. Tahani et al. [3] showed the waste heat recovery from $12 \mathrm{lt}$. CI engine using organic Rankine cycle. In the study, two different configuration of organic Rankine cycle (ORC) for waste heat recovery from exhaust gas and coolant: preheat configuration and two stage configuration. An optimized result was given at different working fluids R-134a, R-123 and R-245fa. The 
power generation and cycle thermal efficiency were maximized. Finally it was found that R-123 is the best working fluid which gave best performance and increase thermal efficiency by $11.73 \%$ and $13.56 \%$ respectively in both configurations. It was also observed that preheating configuration has better result if $\mathrm{R}-134 \mathrm{a}$ is used as working fluid in both configuration but preheat configuration was not sufficient to recover total heat due to mass flow rate limitation. Alberto Boretti [2] showed optimum speed power turbine to recover the exhaust heat of CI diesel and gas engine. This was done by using turbocharger and intercooler and improvement was shown in fuel conversion efficiency at optimum speed. The exhaust energy is recovered by the power turbine that operates at optimum speed. A by-pass and continuously variable transmission (CVT) link is used to crankshaft. Gear ratio between power turbine and crankshaft is replaced by CVT. Due to this advantage power turbine decoupled from the speed of crank shaft.

Chauhan [4] presented a review on recovery of waste heat in IC engine. The study discussed six technologies to recover the waste heat which has come from the exhaust gas of IC engines viz. turboelectric generator technique, organic Rankine cycle technique, six stroke cycle technique, new development in turbocharger technique and combination of these techniques. These techniques have some merits and demerits, but useful to recover waste heat from exhaust.

Bibin et al. [1] carried out a study on waste heat recovery in a hybrid engine with supplementary combustion chamber. In this study waste heat was utilized by producing the electrical energy with the help of turbocharger. The waste heat is utilized to burn the additional amount of the fuel. The thermoelectric generator which was used in produces electrical energy. Finally energy was recovered by the combination of compressor and alternator that was coupled with the turbine.

Kumar et al. [5] studied a waste heat recovery in IC engine using thermos-electric technology. In the study a heat exchanger and 18 thermoelectric generator modules were designed and tested in test rig and overall efficiency of an engine was improved by using waste heat. Thermoelectric module was used as a generator which was a solid state device that converts thermal energy into electrical energy from a temperature gradient. Its principle was based on Seebeck effect. Thermoelectric modules were selected on the basis of temperature differences between exhaust side and engine coolant side.

Rashad et al. [6] studied a single cylinder diesel engine performance under recycling and conditioning of exhaust for air intake. In the study a single cylinder air cooled engine having $8.3 \mathrm{HP}$ and running at $1500 \mathrm{rpm}$ was tested at test rig for measuring parameters. The engine was operated in different conditions viz. increase $\mathrm{O}_{2}$ percentage in an open mode up to $30 \%$ and increase $\mathrm{CO}_{2}$ in inlet charge for close mode operation. The results showed that inlet charge leads to increase the rated brake power with increasing $\mathrm{O}_{2}$ percentage and decreases fuel consumption and increase brake mean effective pressure. $\mathrm{CO}_{2}$ presence in inlet charge show harmful effect on engine performance. A theoretical model was also presented to predict overall performance.

\section{EXPERIMENTATION}

After the combustion process in IC engines, efficiency of engine is low due to high amount of heat losses. This heat loss is either by the exhaust gas or coolant. So there are various parameters that affect the thermal efficiency and bsfc of the engine. Direct injection and indirect injection are the injection methods that affect the performance of a CI engine. Many assumptions and operating factor affect the performance of the engine.

- Compression ratio: mechanical efficiency reduces on increasing the compression ratio due to increase in weight of reciprocating parts.

- Engine speed: on increasing the engine speed, loss of the heat during compression decreases.

- Engine output: with an increase in engine output the air fuel ratio decreases.

- Injection timing: for higher ignition advance pressure and temperature at the beginning of injection are lower.

- Quality of the fuel: lower self-ignition temperature must be use for better performance.

- Intake temperature: on increasing the intake temperature, compressed air temperature increase causes delay period reduces.

- Intake pressure: on increasing the intake pressure reduces the auto ignition temperature.

So assumptions are based on these factors that can increase the performance of engine. The objective of the present work is to study the recovery of waste heat exhaust gas by vaporization of fuel through a small heat exchanger. An amount of fuel is vaporized by the self-made heat exchanger. Copper tube is use in heat exchanger for the heat recovery and flow is parallel flow in the shell and tube heat exchanger. 
ELK

Asia Pacific Journals

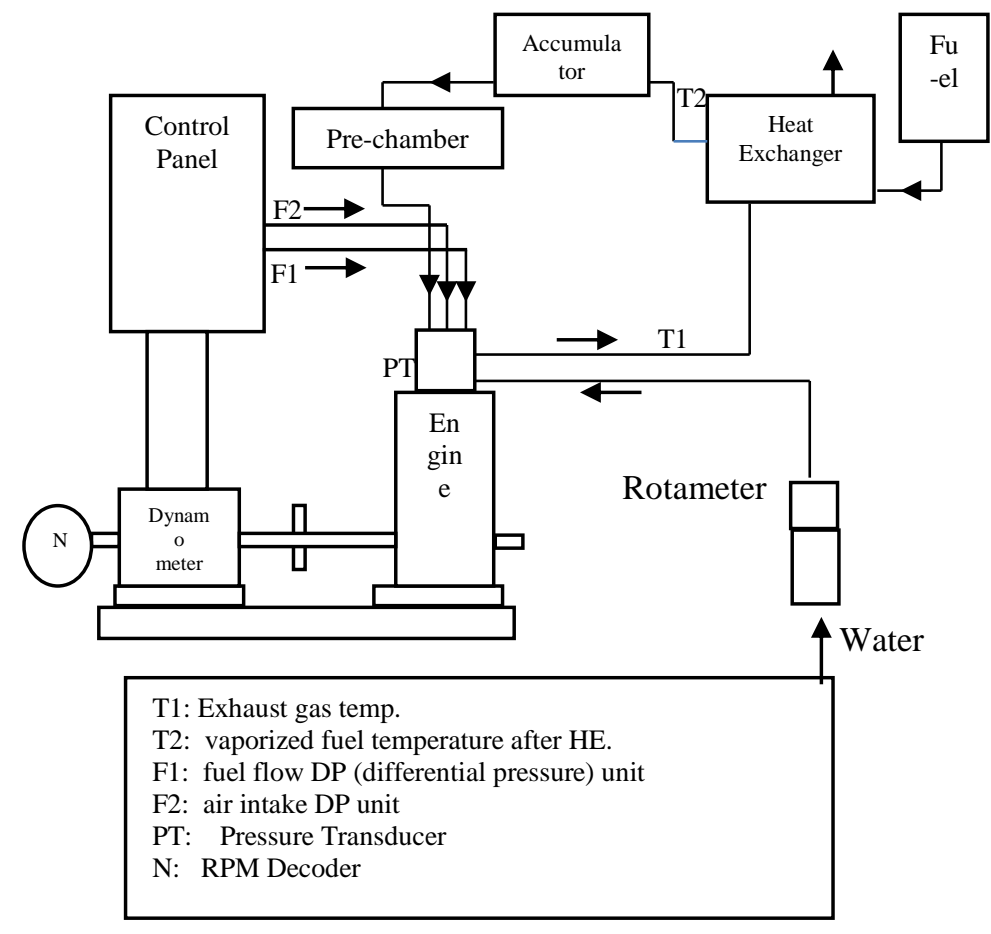

Fig 1: Schematic of experimental setup

The experiment is conducted on modified single cylinder water cooled engine that runs at $1500 \mathrm{rpm}$ having $5.2 \mathrm{~kW}$ power. The experimental setup is shown in Fig 1 and test rig specification is given in Table 1. To conduct the experiment, firstly a heat exchanger is selected for waste heat recovery. The diameter of the heat exchanger is optimized and other parameters viz. length and thickness of heat exchanger are found out. Copper pipes are used inside the heat exchanger of length $2000 \mathrm{~mm}$.

TABLE 1: ENGINE SPECIFICATIONS

\begin{tabular}{|l|l|}
\hline Manufacture & Kirloskar Oil Engine Ltd., Pune \\
\hline Engine & $\begin{array}{l}\text { Single Cylinder. 4-Stroke, water } \\
\text { cooled diesel engine }\end{array}$ \\
\hline Bore & $87.5 \mathrm{~mm}$ \\
\hline Stroke & $110 \mathrm{~mm}$ \\
\hline Comp. Ratio & 17.5 \\
\hline Capacity & $661 \mathrm{cc}(0.661 \mathrm{Ltrs})$ \\
\hline Power & $5.2 \mathrm{~kW}$ at $1500 \mathrm{rpm}$ \\
\hline Sp. Fuel Combustion & $220 \mathrm{gms} / \mathrm{kW}$-hr $(0.22 \mathrm{~kg} / \mathrm{kW}-\mathrm{hr})$ \\
\hline RPM & $1500 \mathrm{rpm}$ \\
\hline BHP@ $1500 \mathrm{rpm}$ & $5.2 \mathrm{~kW}$ \\
\hline Cooling System & Water Cooled \\
\hline
\end{tabular}

Experiment is done on the test rig. The engine which is used in this experiment is run on dual mode: one without diesel vapor mixture and another with diesel vapor mixture. Firstly all
ELK Asia Pacific Journals - Special Issue ISBN: 978-81-930411-4-7

readings without diesel vapor mixture are measured. The supply valve of water for engine is open first. Now fuel supply is started and time taken is measured with the help of digital stop watch for the fuel consumption. The first load is set and first reading of exhaust temp at $27^{\circ}$ crank angle injection timing on computer through the thermocouple noted down. Time is taken for the first $20 \mathrm{cc}$ of fuel. This procedure continues for next load and found all reading for exhaust gas temperature without diesel vapor mixture at $27^{\circ}$ crank angle injection timing. Similarly all procedure is continued at $30^{\circ}$ crank angle injection timing and $27^{\circ}$ crank angle injection timing with direct port supply (DPS).

Now experiment testing is done with the diesel vapor fuel mixture. A heat exchanger is used to this process. A constant supply of exhaust gas is used through the differential valve. Only $4 \%$ of exhaust gas is used in this process. Now the fuel supply is started to the heat exchanger this fuel is vaporized by the heat exchanger. Again time taken is measured with the help of stop watch. Now diesel vapor mixture is used in intake system which is supplied by the accumulator. Again the loads are set and measured all reading at $27^{\circ}$ crank angle injection timing. Similarly all readings are measured at $30^{\circ}$ crank angle injection timing and $27^{\circ}$ crank angle injection timing with DPS.

A heat exchanger-accumulator mechanism is used to vaporize the fuel and catalytic cracking. Accumulator has $20 \mathrm{~mm}$ inner shell diameter and $50 \mathrm{~mm}$ of outer shell diameter. Accumulator is mounted on intake manifold to supply the diesel fuel in vapor form and it is mixed with air into intake system. Fig 2 shows the schematic of heat exchanger and its specifications are presented in Table 2.

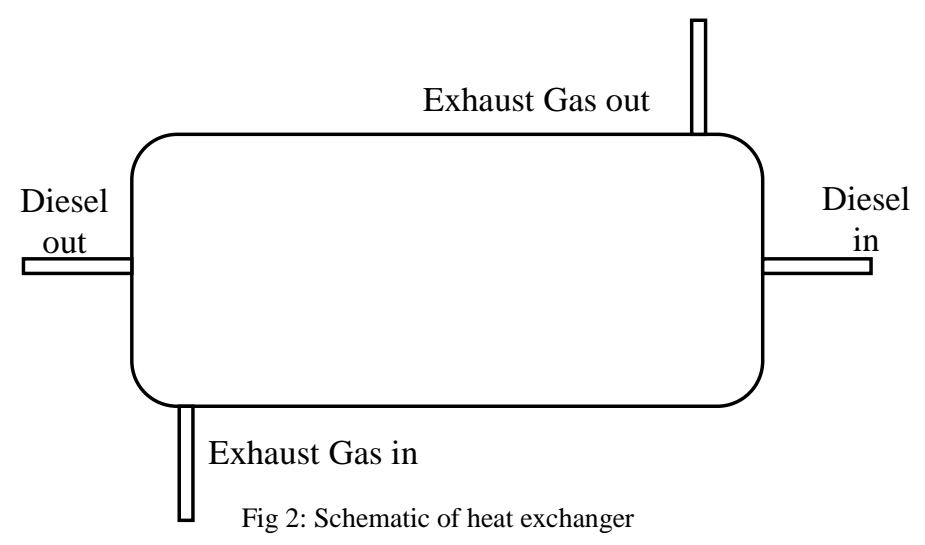

TABLE 2: SPECIFICATIONS OF HEAT EXCHANGER

\begin{tabular}{|c|c|c|}
\hline $\begin{array}{c}\text { S. } \\
\text { No. }\end{array}$ & Particular & $\begin{array}{c}\text { Dimension } \\
(\mathbf{m m})\end{array}$ \\
\hline 1 & Diameter & 420 \\
\hline 2 & Length & 280 \\
\hline 3 & Thickness of the cylinder & 2 \\
\hline 4 & Diameter of the copper pipe & 12 \\
\hline
\end{tabular}


ELK

Asia Pacific Journals
ELK Asia Pacific Journals - Special Issue ISBN: 978-81-930411-4-7

\begin{tabular}{|c|c|c|c|c|}
\hline $\begin{array}{c}\text { Load } \\
(\mathrm{kg})\end{array}$ & $\begin{array}{c}\text { Exhaust } \\
\text { temp. } \\
\left({ }^{0} \mathrm{C}\right) \\
\end{array}$ & $\begin{array}{c}\text { Voltage } \\
\text { (V) }\end{array}$ & $\begin{array}{l}\text { Current } \\
\text { (A) }\end{array}$ & 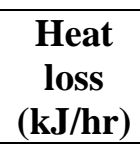 \\
\hline 0 & 300 & 240 & - & 12892.5 \\
\hline 5 & 340 & 240 & 5 & 13923.9 \\
\hline 10 & 380 & 240 & 8 & 15986.7 \\
\hline 15 & 395 & 240 & 12.5 & 17533.8 \\
\hline 20 & 405 & 240 & 17.5 & 19080.9 \\
\hline 25 & 430 & 240 & 22 & 20628 \\
\hline 30 & 460 & 240 & 26 & 21146.4 \\
\hline $\begin{array}{l}\text { S. } \\
\text { No. }\end{array}$ & \multicolumn{2}{|c|}{ Particular } & \multicolumn{2}{|c|}{$\begin{array}{c}\text { Dimension } \\
(\mathbf{m m})\end{array}$} \\
\hline 5 & \multicolumn{3}{|c|}{ Length of the copper pipe } & 2000 \\
\hline
\end{tabular}

IV. DATA ANALYSIS

The engine is tested at different loads from $5 \mathrm{~kg}$ to $30 \mathrm{~kg}$ at different time intervals, by connecting a thermocouple at the engine's exhaust. Heat loss through the exhaust gas from internal combustion is calculated as follows. The following data were assumed for the study [7]

- $\quad$ Volumetric efficiency is 0.8 to 0.9

- Density of diesel fuel is 0.71 to $0.85 \mathrm{gm} / \mathrm{cc}$

- Calorific value of diesel is 42 to $45 \mathrm{MJ} / \mathrm{kg}$

- Density of vapor fuel is $1.167 \mathrm{~kg} / \mathrm{m}^{3}$

- Specific heat of exhaust gas is $1.1-1.25 \mathrm{KJ} / \mathrm{kg}{ }^{\circ} \mathrm{K}$

Exhaust heat loss through diesel engine:

Compression ratio (r):

$$
\begin{aligned}
& \mathrm{r}=\left(\mathrm{V}_{\mathrm{c}}+\mathrm{V}_{\mathrm{s}}\right) / \mathrm{V}_{\mathrm{c}} \\
& \mathrm{V}_{\mathrm{c}}=4 \times 10^{-5} \mathrm{~m}^{3}
\end{aligned}
$$

Total volume $\left(\mathrm{V}_{\mathrm{t}}\right)=\mathrm{V}_{\mathrm{c}}+\mathrm{V}_{\mathrm{s}}=7.01 \times 10^{-4} \mathrm{~m}^{3}$

Mass flow rate of fuel (on the basis of specific fuel consumption) $\dot{\mathrm{m}}_{\mathrm{f}}$

s.f.c $=\dot{\mathrm{m}}_{\mathrm{f}} /$ power

$\dot{\mathrm{m}}_{\mathrm{f}}=0.3177 \mathrm{gms} / \mathrm{sec}$

Volume rate $=$ swept volume $\times$ speed

Volume rate $(\mathrm{V})=\mathrm{V}_{\mathrm{s}} \times \mathrm{N}$

$$
=8.262 \times 10^{-3} \mathrm{~m}^{3} / \mathrm{sec}
$$

Volumetric efficiency $\left(\eta_{\mathrm{v}}\right)$

$$
\begin{aligned}
\eta_{\mathrm{v}} & =\text { volume of air/ swept volume } \\
\eta_{\mathrm{v}} & =\dot{\mathrm{m}}_{\mathrm{a}} / \rho_{\mathrm{a}} \times \mathrm{n} \times \mathrm{V}_{\mathrm{s}} \\
\dot{\mathrm{m}}_{\mathrm{a}} & =\eta_{\mathrm{v}} \times \rho_{\mathrm{a}} \times \mathrm{n} \times \mathrm{V}_{\mathrm{s}} \\
& =8.625 \mathrm{gm} / \mathrm{sec}
\end{aligned}
$$

Mass flow rate of exhaust gas $\left(\dot{\mathrm{m}}_{\mathrm{E}}\right)$

$$
\dot{\mathrm{m}}_{\mathrm{E}}=\dot{\mathrm{m}}_{\mathrm{f}}+\dot{\mathrm{m}}_{\mathrm{a}}=8.9427 \times 10^{-3} \mathrm{~kg} / \mathrm{sec}
$$

Heat loss in exhaust gas $\left(\mathrm{Q}_{\mathrm{E}}\right)=\dot{\mathrm{m}}_{\mathrm{E}} \times \mathrm{C}_{\mathrm{p}} \times \Delta \mathrm{T}$

$$
=4.13 \mathrm{~kJ} / \mathrm{sec}(\text { or } \mathrm{kW})
$$

Table 3 show the exhaust temperature measurement by thermocouple at different loads and Table 4 shows the time for $20 \mathrm{cc}$ of fuel.

TABLE 3: EXHAUST TEMPERATURE MEASUREMENT
TABLE 4: TIME FOR 20 CC OF FUEL

\begin{tabular}{|c|c|}
\hline Load (kg) & Time (sec) \\
\hline 0 & 84 \\
\hline 5 & 76 \\
\hline 10 & 62 \\
\hline 15 & 53 \\
\hline 20 & 47 \\
\hline 25 & 34 \\
\hline 30 & 26 \\
\hline
\end{tabular}

A. Design for the heat exchanger

Mass flow rate of exhaust gas which is flowing in heat exchanger, we are using only $4 \%$ of mass flow rate of total exhaust gas. Table 5 and Table 6 show the mass flow rate of exhaust gas and fuel at different loads.

TABLE 5: MASS FLOW RATE OF EXHAUST GAS AT DIFFERENT LOADS

\begin{tabular}{|c|c|}
\hline Load (kg) & Mass flow rate (kJ/s) \\
\hline 0 & $3.5 \times 10^{-4}$ \\
\hline 5 & $3.6 \times 10^{-4}$ \\
\hline 10 & $3.8 \times 10^{-4}$ \\
\hline 15 & $3.9 \times 10^{-4}$ \\
\hline 20 & $4.0 \times 10^{-4}$ \\
\hline 25 & $4.4 \times 10^{-4}$ \\
\hline 30 & $4.79 \times 10^{-4}$ \\
\hline
\end{tabular}

TABLE 6: MASS FLOW RATE OF FUEL AT DIFFERENT LOADS

\begin{tabular}{|c|c|}
\hline Load (kg) & Mass flow rate (kJ/s) \\
\hline 0 & 0.053 \\
\hline 5 & 0.06 \\
\hline 10 & 0.068 \\
\hline 15 & 0.080 \\
\hline 20 & 0.081 \\
\hline 25 & 0.09 \\
\hline 30 & 0.095 \\
\hline
\end{tabular}

Table 7 and Table 8 show the inlet temperature of hot fluid $\mathrm{T}_{\mathrm{h} 1}$ and outlet temperature of hot fluid $\mathrm{T}_{\mathrm{h} 2}$. From these two tables we can design the heat exchanger.

TABLE 7: INLET TEMPERATURE OF HOT FLUID

\begin{tabular}{|c|c|}
\hline Load (kg) & Temperature $\left({ }^{\mathbf{0}} \mathbf{C}\right)$ \\
\hline 0 & 300 \\
\hline 5 & 340 \\
\hline 10 & 380 \\
\hline
\end{tabular}


ELK

Asia Pacific Journals

\begin{tabular}{|l|l|}
\hline 15 & 395 \\
\hline 20 & 405 \\
\hline 25 & 430 \\
\hline 30 & 460 \\
\hline
\end{tabular}

TABLE 8: OUTLET TEMPERATURE OF HOT FLUID

\begin{tabular}{|c|c|}
\hline Load (kg) & Temperature $\left({ }^{\mathbf{0}} \mathbf{C}\right)$ \\
\hline 0 & 270 \\
\hline 5 & 300 \\
\hline 10 & 335 \\
\hline 15 & 355 \\
\hline 20 & 370 \\
\hline 25 & 385 \\
\hline 30 & 400 \\
\hline
\end{tabular}

Inlet temperature of cold fluid $\left(\mathrm{T}_{\mathrm{c} 1}\right)$ is $30^{\circ} \mathrm{C}$. Now equation for heat balance is:

Heat gain by cold fluid $=$ heat loss by hot fluid

$$
\begin{gathered}
\dot{\mathrm{m}}_{\mathrm{c}} \times \mathrm{C}_{\mathrm{c}} \times \Delta \mathrm{T}_{\mathrm{lm}}=\dot{\mathrm{m}}_{\mathrm{h}} \times \mathrm{C}_{\mathrm{h}} \times \Delta \mathrm{T}_{\mathrm{lm}} \\
\mathrm{T}_{\mathrm{c} 2}=330 \mathrm{~K}
\end{gathered}
$$

Rate of heat transfer $(\mathrm{Q})=\dot{\mathrm{m}}_{\mathrm{c}} \times \mathrm{C}_{\mathrm{c}} \times \Delta \mathrm{T}$

$$
=3.9 \mathrm{~kW}
$$

LMTD:

$\left.\left.\mathrm{T}_{\mathrm{h} 1}\right)+\left(\mathrm{T}_{\mathrm{c} 1}-\mathrm{T}_{\mathrm{c} 2}\right)\right]$

$$
\ln \left[\left(\mathrm{T}_{\mathrm{h} 2}-\mathrm{T}_{\mathrm{c} 2}\right) /\left(\mathrm{T}_{\mathrm{h} 1}-\mathrm{T}_{\mathrm{c} 1}\right)\right]=(\mathrm{UA} / \mathrm{Q})^{*}\left[\left(\mathrm{~T}_{\mathrm{h} 2}-\right.\right.
$$

$A=0.1266048 \mathrm{~m}^{2}$

Area of the tube, $\quad A_{t}=\dot{m}_{h} / \rho v$

$$
\text { But, } \quad \begin{aligned}
& =1.3682 * 10-3 \mathrm{~m}^{2} \\
\mathrm{~A}_{\mathrm{t}} & =\pi \mathrm{d}^{2} / 4 \\
\mathrm{~d} & =0.012 \mathrm{~m}
\end{aligned}
$$

Length of the tube,

$$
\begin{aligned}
& \mathrm{A}=\pi \mathrm{dL} \\
& \mathrm{L}=0.28 \mathrm{~m}
\end{aligned}
$$

Diameter of the heat exchanger,

$$
\begin{aligned}
& \mathrm{A}=\pi \mathrm{D}^{2} / 4 \\
& \mathrm{D}=0.4015 \mathrm{~m}
\end{aligned}
$$

\section{RESUlTS \& DisCUSSIONS}

As performance characteristics are given by the brake thermal efficiency and bsfc. Thus results obtained from the experiment shows the variation of brake thermal efficiency and bsfc with respect to brake power.

\section{A. Brake Thermal Efficiency}

Fig 3 shows the variation of brake thermal efficiency without diesel vapor mixture and with diesel vapor mixture at $27^{\circ}$ crank angle for injection timing. This graph shows the variation in brake thermal efficiency at various loads i.e. with brake power at $50 \%, 75 \%$ and $100 \%$ load conditions. The brake power is $2.388 \mathrm{~kW}$ with $50 \%$ load at $27^{\circ}$ crank angle
ELK Asia Pacific Journals - Special Issue ISBN: 978-81-930411-4-7

injection timing, corresponding to these values, the brake thermal efficiency without diesel vapor mixture is 0.238 and with diesel vapor mixture are 0.262 . Also the brake powers were 3.544 and 4.776 at $75 \%$ and $100 \%$ load respectively, corresponding to these values, the brake thermal efficiencies without diesel vapor mixture are 0.251 and 0.252 and with diesel vapor mixture brake thermal efficiency are 0.283 and 0.290 respectively. This shows $10 \%$ increment with $50 \%$ load, $13 \%$ increment with $75 \%$ load and $15 \%$ increment with $100 \%$ load in brake thermal efficiency are obtained when diesel vapor mixture is used.

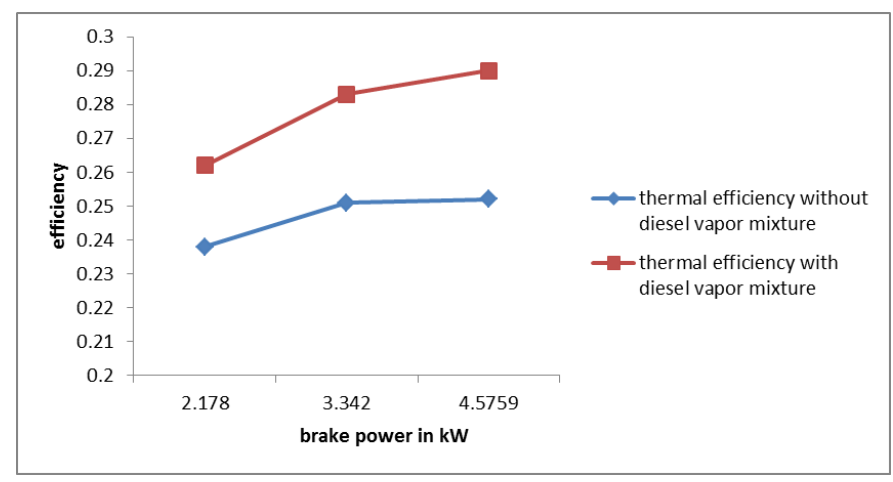

Fig 3: Variation in brake thermal efficiency without diesel vapor mixture and with diesel vapor mixture at $27^{\circ}$ crank angle injection timing

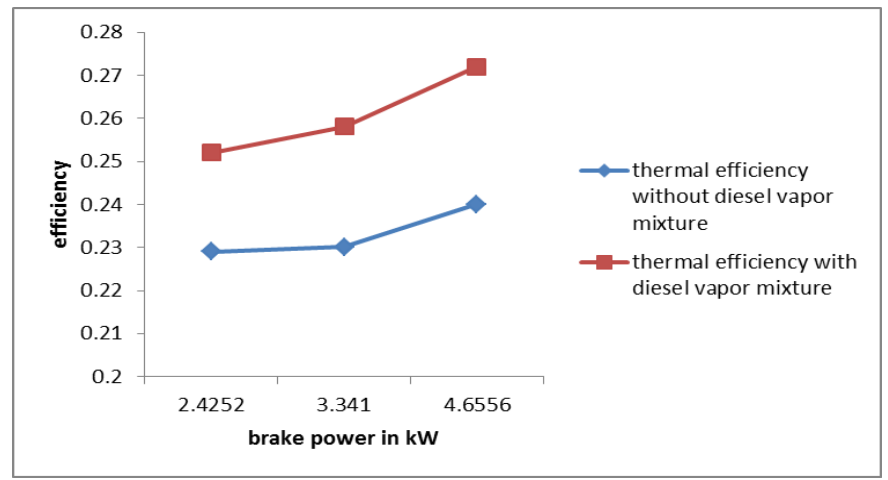

Fig 4: Variation in brake thermal efficiency without diesel vapor mixture and with diesel vapor mixture at $30^{\circ}$ crank angle injection timing

Fig 4 shows the graph of brake thermal efficiency without diesel vapor mixture and with diesel vapor mixture at $30^{\circ}$ crank angle injection timing. This graph again shows the variation in brake thermal efficiency with brake power at $50 \%$, $75 \%$ and $100 \%$ load conditions. The brake power is 2.6196 $\mathrm{kW}$ with $50 \%$ load at $30^{\circ}$ crank angle injection timing, corresponding to these values, the brake thermal efficiency without diesel vapor mixture is 0.229 and with diesel vapor mixture is 0.252 . The brake powers at $75 \%$ and $100 \%$ load are 3.542 and 4.7426 respectively, corresponding to these values, the brake thermal efficiencies without diesel vapor mixture are 
ELK

\section{Asia Pacific Journals}

0.2301 and 0.240 and with diesel vapor mixture brake thermal efficiency are 0.2581 and 0.272 respectively. This shows $10.19 \%$ increment with $50 \%$ load, $12.12 \%$ increment with $75 \%$ load and $13.6 \%$ increment with $100 \%$ load in brake thermal efficiencies with use of diesel vapor mixture.

Similarly graph plotted at $27^{\circ}$ crank angle injection timing with direct port supply (DPS) in Fig 5. The brake power is $2.388 \mathrm{~kW}$ with $50 \%$ load at $27^{\circ}$ crank angle injection timing with DPS, thus the brake thermal efficiency without diesel vapor mixture is 0.245 and with diesel vapor mixture is 0.279 . The brake powers are 3.544 and 4.776 with $75 \%$ and $100 \%$ load respectively at $27^{\circ}$ crank angle injection timing with DPS, giving the brake thermal efficiencies without diesel vapor mixture of 0.249 and 0.259 and with diesel vapor mixture 0.281 and 0.31 respectively. Hence showing $14 \%$ increment at $50 \%$ load, $12.17 \%$ increment at $75 \%$ load and $19.8 \%$ increment at $100 \%$ load in brake thermal efficiencies when diesel vapor mixture at $27^{0}$ crank angle injection timing with DPS is used.

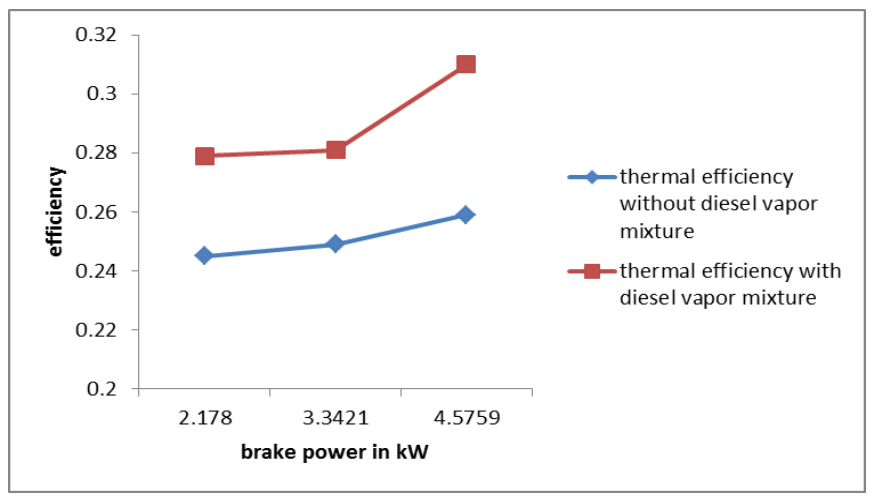

Fig 5: Variation in brake thermal efficiency without diesel vapor mixture and with diesel vapor mixture at $27^{\circ}$ crank angle injection timing with DPS

At $27^{\circ}$ injection timing with DPS, the increment in brake thermal efficiency is more because of charge potential is better than to others. There is a fine mixing of charges inside the engine cylinder at this injection timing and reduce the delay period for combustion causes peak pressure increase and less fuel consumption achieved.

\section{B. Brake Specific Fuel Consumption}

Same as the brake thermal efficiency, brake specific fuel consumption was shown in Fig 6. These graphs are plotted at $27^{\circ}, 30^{\circ}$ and $27^{\circ}$ with DPS injection timing.

Fig 6 shows the graph of bsfc without diesel vapor mixture and with diesel vapor mixture at $27^{\circ}$ crank angle injection timing. This graph shows the variation in bsfc with brake power at $50 \%, 75 \%$ and $100 \%$ load conditions. The brake power is $2.388 \mathrm{~kW}$ with $50 \%$ load at $27^{\circ}$ crank angle injection timing, corresponds to these values, bsfc without diesel vapor
ELK Asia Pacific Journals - Special Issue ISBN: 978-81-930411-4-7

mixture is 0.38 and with diesel vapor mixture is 0.31 . The brake powers are 3.544 and 4.776 at $75 \%$ and $100 \%$ load respectively and the bsfc without diesel vapor mixture are 0.33 and 0.32 and with diesel vapor mixture bfsc are 0.305 and 0.301 respectively. Hence $5.9 \%$ reduction of bsfc at full load condition when with diesel vapor mixture is achieved.

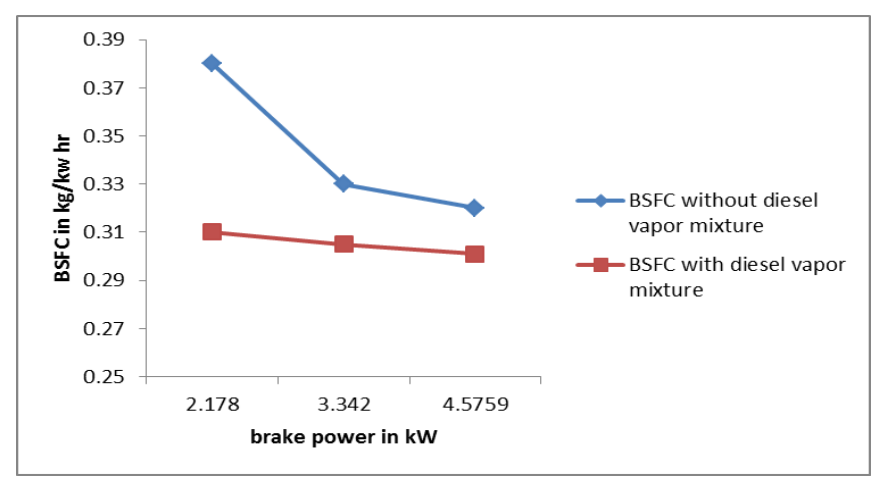

Fig 6: Variation in bsfc at $27^{\circ}$ crank angle injection timing

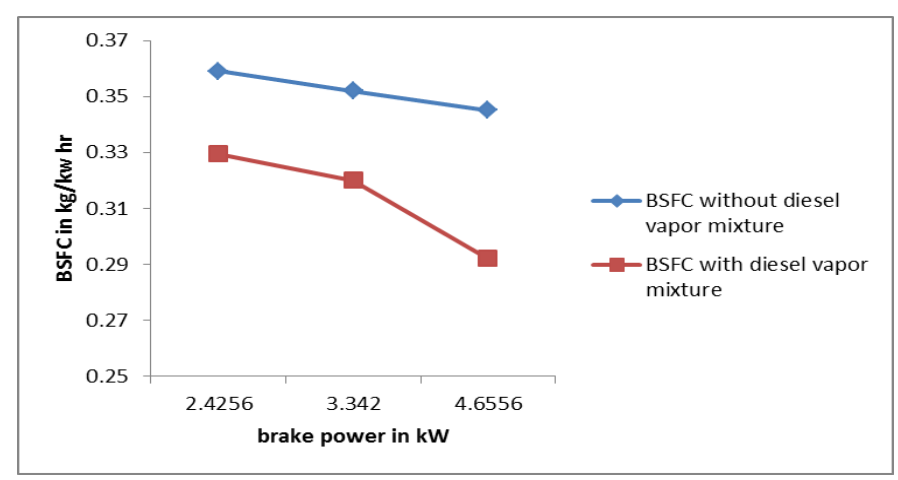

Fig 7: Variation in bsfc at $30^{\circ}$ crank angle injection timing

Fig 7 shows the graph bsfc without diesel vapor mixture and with diesel vapor mixture at $30^{\circ}$ crank angle injection timing. The brake power is $2.6196 \mathrm{~kW}$ with $50 \%$ load at $30^{\circ}$ crank angle injection timing which gives the bsfc without diesel vapor mixture of 0.359 and with diesel vapor mixture of 0.3295 . The brake powers are 3.542 and 4.742 at $75 \%$ and $100 \%$ load respectively, corresponding these valves, the bsfc without diesel vapor mixture are 0.352 and 0.345 and with diesel vapor mixture bfsc are 0.32 and 0.292 respectively, hence showing $15 \%$ reduction in the bsfc at full load condition with diesel vapor mixture.

Fig 8 shows the graph of bsfc without diesel vapor mixture and with diesel vapor mixture at $27^{\circ}$ crank angle injection timing with dps. This graph shows the variation in bsfc with brake power at $50 \%, 75 \%$ and $100 \%$ load conditions. The brake power is $2.388 \mathrm{~kW}$ with $50 \%$ load at $27^{\circ}$ crank angle injection timing with dps, the bsfc without diesel vapor 
ELK

\section{Asia Pacific Journals}

mixture is 0.378 and with diesel vapor mixture is 0.27 . The brake powers are 3.544 and 4.776 with $75 \%$ and $100 \%$ load respectively, corresponds to the bsfc without diesel vapor mixture of 0.339 and 0.302 and with diesel vapor mixture bfsc of 0.263 and 0.260 respectively, hence giving $13.9 \%$ reduction in the bsfc at full load condition with diesel vapor mixture.

So bsfc at $27^{\circ}, 30^{\circ}$ and $27^{\circ}$ injection timing is calculated with dps from the graphs the optimum condition is found at $30^{\circ}$ crank angle injection timing. At this condition there is the maximum reduction of $15 \%$ in bsfc.

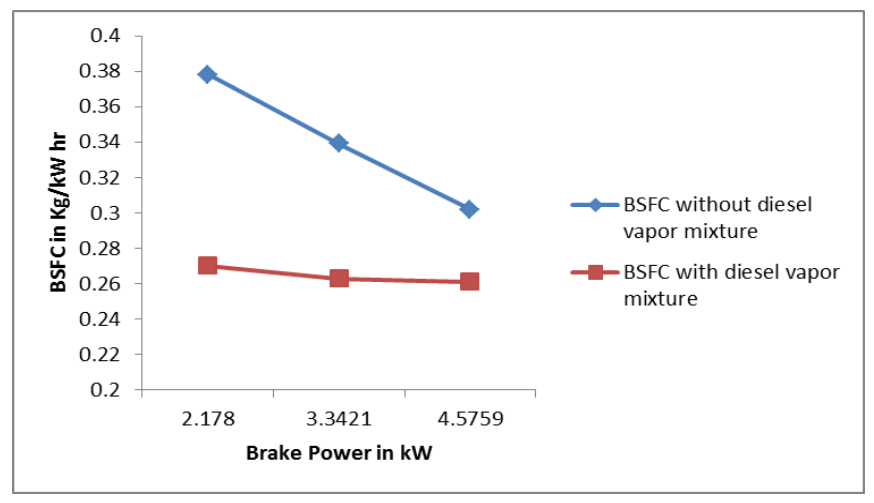

Fig 8: Variation in bsfc at $27^{\circ}$ crank angle injection timing with DPS

\section{CONCLUSION}

The heat which is considered as waste heat come from the exhaust gases can be utilized by vaporization of diesel. This evaporated fuel mix with the intake air and burns completely. It reduces the delay period which causes increase in combustion pressure and develops more power. Due to the proper mixing, the charge burns completely and there is no unburnt hydro carbon present in exhaust thereby reducing the emissions. Specific heat of fuel increases due to vaporizing and bsfc is decreases significantly. The fuel ignites at multiple
ELK Asia Pacific Journals - Special Issue

ISBN: 978-81-930411-4-7

points and no flame propagates in combustion chamber thereby perfect combustion takes place causing less emission. The percentage increment in brake thermal efficiency with diesel vapor mixture is $15 \%$ at full load $27^{\circ}$ injection timing, $13 \%$ at $30^{\circ}$ injection timing and $19.8 \%$ for $27^{\circ}$ DPS. Thermal efficiency is high in case of $27^{\circ}$ injection timing with DPS due to perfect mixing and air-fuel ratio. It is also observed that brake specific fuel consumption reduces by $5.44 \%$ for $27^{\circ}$, $15 \%$ for $30^{\circ}$ and $14 \%$ for $27^{\circ}$ with DPS as the load increases. So $30^{\circ}$ injection timing is the optimum condition for the brake specific fuel consumption. This shows the advantage of combustion of diesel vapor with the recovery of heat from exhaust gases that can be used to obtain less fuel consumption and increasing thermal efficiency at decrease load condition.

\section{References}

[1] Bibin, Y. Kojima, K. Takahashi, Baba T., Ibaraki S., Takahashi T., Study on Maximizing Exergy in Automotive Engines, SAE Int. Publication 2012-01-0257, 2007.

[2] Boretti A, Optimum Speed Power Turbine to Recover the Exhaust Energy of Compression Ignition Diesel and Gas Engines SAE Int. Publication 2012-01-0537 (2012).

[3] Tahani, E. Bellos A, Kakaras E., A comprehensive study on waste heat recovery by organic rankine cycle, June 26-29, 2013, Perugia, Italy.

[4] Chauhan V, A Review of research in mechanical engineering on recovery of waste heat in internal combustion engine, International Journal Of Research In Engineering \& Applied Sciences, 2012, 2 (12) 2249-3905.

[5] Kumar R., Sonthalia A, Goel R, Experimental study on waste heat recovery from an internal combustion engine using thermoelectric technology, Thermal Science, 2011, 15 (4), 1011-22.

[6] Rashad AM, Investigation of a single cylinder diesel engine performance under recycling and conditioning of exhaust for air intake, Transactions of the Japan Society of Mechanical Engineers, Part B 70 (689) (2009) 292-299.

[7] Xuejun H, Deli G., Analysis of Exhaust Gas Waste Heat Recovery and Pollution Processing for Z12V190 Diesel Engine, Maxwell Scientific Organization, Res. J. Appl. Sci. Eng. Technol., 2012, 4, 1604-11. 